\title{
Phân khúc nhà ở chung cư cho người thu nhập thấp tại Việt Nam
}

\section{Apartment market for low income segment in Vietnam}

\author{
Võ Hà Duy ${ }^{1,2^{*}}$ \\ ${ }^{1}$ Trường Đại học Mở Thành phố Hồ Chí Minh, Việt Nam \\ ${ }^{2}$ Bệnh viện Nguyễn Tri Phương \\ *Tác giả liên hệ, Email: duyvh.208m@ou.edu.vn
}

THÔNG TIN

DOI: $10.46223 / \mathrm{HCMCOUJS.}$ proc.vi.16.1.1862.2021

Ngày nhận: 7/3/2021

Ngày nhận lại: 31/3/2021

Duyệt đăng: 8/4/2021

Tù khóa:

nhà ở xã hội, quy chuẩn Việt Nam

Keywords:

Social housing, Vietnamese standards

\section{TÓM TẮT}

Phân khúc nhà ở chung cư cho người thu nhập thấp tại Việt Nam đang thiếu nguồn cung, chưa có nhiều doanh nghiệp đầu tư bất động sản chuyên nghiệp thực hiện. Việc triển khai và quản lý cho phân khúc này còn gặp nhiều khó khăn. Nội dung bài viết này trình bày cơ sở pháp lý hiện nay tại Việt Nam, kinh nghiệm một số nước trên thế giới và lấy kinh nghiệm thực tiễn đó để có thể vận dụng vào mô hình phân khúc nhà ở chung cư cho người có thu nhập thấp tại Việt Nam. Kết quả nghiên cứu là cơ sở cho các đề xuất chính sách khi xây dựng căn hộ chung cư cho người có thu nhập thấp để cho các doanh nghiệp kinh doanh địa ốc chuyên nghiệp và có uy tín trên thị trường bất động sản mạnh dạn đầu tư vào phân khúc nhà ở chung cư, nhà ở xã hội cho người thu nhập thấp, để từ đó ai cũng sở hữu được căn nhà hoặc đi thuê với giá phải chăng, góp phần vào sự thành công của mô hình này ở Việt Nam.

\section{ABSTRACT}

The segmentation of apartment for low-income people in Vietnam is short of supply, there are not many professional real estate investors planning to those projects. The implementation and management for this segment are still facing many difficulties. This article reveals the current legal system in Vietnam,experiences in some countries around the world and then takes those practical experiences to apply to the model of the apartment segment for low-income citizen in Vietnam. The research results are the basis for policy proposals when building apartments in order to appeal professional and reputable real estate businesses investing to this type of market thus, everyone can own a house or rent at reasonable price which contributes to the success of this model in Vietnam.

\section{Giới thiệu}

Trong những năm gần đây thị trường bất động sản đang diễn ra nhu cầu dư thừa nhà ở thuộc phân khúc trung cao cấp với diện tích lớn, giá bán cao nhưng lại thiếu phân khúc nhà ở bình dân cho người có thu nhập thấp có tính pháp lý rõ ràng và minh bạch được sở hữu một căn nhà luôn là mơ ước của nhiều người lao động. Tuy nhiên với giá nhà, đất và thu nhập khiêm tốn 
của người lao động hiện nay, thì giấc mơ về một căn nhà khó thành hiện thực. Đi tìm lời giải cho phân khúc nhà ở cho người lao động có thu nhập thấp thì vai trò của Nhà nước trong giải quyết nhà ở cho người có thu nhập thấp là hết sức quan trọng.

Cụ thể, nhu cầu nhà ở phân khúc trung, cao cấp có giá dao động bình quân 25 triệu đồng/m2 trở lên chiếm khoảng $20-30 \%$ thị trường từng địa phương và tập trung vào các đô thị lớn.

Thành phố Hồ Chí Minh, thành phố Hà Nội mật độ dân số đông phân khúc nhà ở bình dân giá dưới 25 triệu đồng $/ \mathrm{m}^{2}$ là mơ ước của nhiều người có thu nhập thấp chiếm khoảng 70 $80 \%$ thị trường nhưng nguồn cung thiếu hụt.

Chính vì nguồn cung thiếu một số doanh nghiệp địa ốc đánh vào tâm lý người có thu nhập thấp cần chổ ở rao bán những mảnh đất giá hời, pháp lý về khu đất chưa rõ ràng người dân đổ xô nhau đi mua và cuối cùng là tiền mất, tài sản không có, điển hình doanh nghiệp địa ốc Alibaba trong năm 2019 Bộ Công an vào cuộc.

Do những doanh nghiệp địa ốc làm ăn không chân chính liên tục xảy ra phân khúc nhà ở bình dân. Bộ Xây dựng vừa ban hành Thông tư 21/2019/TT-BXD và QCVN 04:2019, ngày 31/12/2019 (Bộ Xây dựng, 2019b) về Quy chuẩn kỹ thuật quốc gia về chung cư có hiệu lực thi hành ngày 01 tháng 07 năm 2020. Theo đó căn hộ chung cư có diện tích sử dụng tối thiểu không được nhỏ hơn $25 \mathrm{~m} 2$.

Đây là một chủ trương đúng đắn, Thông tư và Quy chuẩn Việt Nam về Quy chuẩn kỹ thuật quốc gia về nhà chung cư ra đời có những điểm tích cực nhằm tháo gở khó khăn về nhà ở cho người lao động có thu nhập thấp và là cơ sở pháp lý đủ mạnh để những doanh nghiệp địa ốc làm ăn chân chính có uy tính trên thị trường mạnh tay đầu tư vào phân khúc này để cho các đối tượng như người lao động có thu nhập thấp, người nhập cư, người trẻ mới lập gia đình, công chức, viên chức, lực lượng vũ trang....có thể tiếp cận và sử dụng căn hộ hợp pháp để họ an cư lập nghiệp và con cái của họ được học hành và góp phần vào phát triển kinh tế xã hội .

Việc Bộ Xây dựng cho phép xây dựng căn hộ chung cư có diện tích từ $25 \mathrm{~m} 2$ trở lên là hợp lý và trên thực tế giá những căn hộ như vậy có giá từ 500 triệu đồng đến 1 tỷ thì những đối tượng nêu trên có khả năng tiếp cận được

Bên cạnh đó Sở Xây dựng TPHCM đang tham mưu cho UBND thành phố giải quyết chuyển đổi các dự án bất động sản trung, cao cấp đang tồn kho hoặc những chủ đầu tư xin điều chỉnh quy mô căn hộ trung, cao cấp sang phân khúc nhà ở bình dân hoặc nhà ở xã hội để tháo gỡ khó khăn về nhà ở bình dân và nhà ở xã hội.

\section{Cơ sở lý thuyết về căn hộ chung cư}

Căn cứ Luật Nhà ở số 65/2014/QH13 (Quốc hội, 2014a) quy định như sau:

- Nhà chung cư là nhà có 02 tầng trở lên.

- Có nhiều căn hộ

- Có lối đi và cầu thang chung

- Có phần sở hữu riêng

- Có phần sở hữu chung

- Hệ thống hạ tầng kỹ thuật sử dụng chung

- Nhà chung cư xây dựng để ở và sử dụng hổn hợp ở và kinh doanh 


\subsection{Các yêu cầu khi xây dụng căn hộ chung cư và nhà ở xã hội (NOXH)}

- Đảm bảo yêu cầu quy hoạch, kiến trúc, hạ tầng kỹ thuật xã hội, chiều cao công trình.

- Đảm bảo chất lượng công trình xây dựng và bảo trì theo Nghị định số 46/2015/NĐ-CP ngày 12 tháng 05 năm 2015 về quản lý chất lượng và bảo trì công trình xây dựng (Chính phủ, 2015a).

- Đảm bảo tiêu chí đánh giá tác động môi trường theo Nghị định số 40/2019/NĐ-CP ngày 13 tháng 05 năm 2019 quy định sửa đổi bổ sung một số điều và hướng dẫn thi hành Luật bảo vệ môi trường (Chính Phủ, 2019).

- Đảm bảo tiêu chí về Phòng cháy chữa cháy theo Nghị định số 79/2014/NĐ-CP ngày 31 tháng 07 năm 2014 (Chính phủ, 2014) quy định chi tiết một số điều của Luật Phòng cháy chữa cháy.

Theo Thông tu số 31/2016/TT-BXD ngày 30 tháng 12 năm 2016 của Bộ Xây dựng quy định phân hạng chung cu theo Điều 5 với 4 tiêu chí (Bộ Xây dựng, 2016).

+ Tiêu chí Quy hoạch, kiến trúc, chiều cao công trình

+ Tiêu chí về hệ thống, thiết bị kỹ thuật

+ Dịch vụ, hạ tầng kỹ thuật

+ Chất lượng, quản lý vận hành, bảo trì, bảo dưỡng

Nội dung Quy chuẩn kỹ thuật quốc gia về nhà ở chung cư: QCVN 04:2019, ngày 31/12/2019 có hiệu lực thi hành ngày 01 tháng 7 năm 2020 (Bộ Xây dựng, 2019b).

- Diện tích sử dụng: Diện tích căn hộ $>25 \mathrm{~m} 2$

- Số tầng: Số tầng của tòa nhà bao gồm toàn bộ các tầng trên mặt đất (kể cả tầng kỹ thuật, tầng tum) và tầng bán/nửa hầm, không bao gồm tầng áp mái.

- Tầng áp mái: Tầng nằm bên trong không gian của mái dốc mà toàn bộ hoặc một phần mặt đứng của nó được tạo bởi bề mặt mái nghiêng hoặc mái gấp, trong đó tường bao (nếu có) không cao quá mặt sàn $1,5 \mathrm{~m}$

- Tầng trên mặt đất: Tầng mà cao độ sàn của nó cao hơn hoặc bằng cao độ mặt đất đặt công trình theo quy hoạch được duyệt.

- Tầng hầm: Tầng mà cao độ sàn của nó cao hơn hoặc bằng cao độ mặt đất đặt công trình theo quy hoạch được duyệt.

- Tầng nữa hầm: Tầng mà một nửa chiều cao của nó nằm trên hoặc ngang cao độ mặt đất đặt công trình theo quy hoạch được duyệt.

- Tầng kỹ thuật: Tầng hoặc một phần tầng bố trí các gian kỹ thuật hoặc các thiết bị kỹ thuật của tòa nhà. Tầng kỹ thuật có thể là tầng hầm, tầng nửa hầm, tầng áp mái, tầng trên cùng hoặc tầng thuộc phần giữa của tòa nhà.

- Gian kỹ thuật: Gian phòng bố trí các thiết bị kỹ thuật của tòa nhà hoặc tầng nhà. Các gian kỹ thuật có thể bố trí trên toàn bộ hoặc một phần của tầng kỹ thuật.

- Phòng ở: Các phòng trong căn hộ được sử dụng một hoặc nhiều chức năng. Phòng ở là phòng ngủ và phòng sinh hoạt khác.

- Ban Công: Không gian có lan can bảo vệ, nhô ra khỏi mặt tường bao của nhà chung cư. 
- Lô gia: Không gian có lan can bảo vệ, lùi vào so với mặt tường bao của nhà chung cư.

\subsection{Không gian sinh hoạt cộng đồng}

- Không gian được bố trí để tổ chức các hoạt động chung của cư dân sống trong nhà chung cư, cụm nhà chung cư như: hội nghị cư dân, các hoạt động sinh hoạt văn hóa, vui chơi, giải trí và các sinh hoạt cộng đồng khác.

- Sảnh thang máy

- Không gian trống trước cửa ra vào của thang máy.

- Khoang đệm

- Không gian chuyển tiếp giữa hai cửa đi, dùng để bảo vệ tránh sự xâm nhập của khói và các khí khác khi đi vào nhà, vào buồng thang bộ hoặc các gian phòng khác của nhà.

- Khoang cháy

- Một phần của ngôi nhà được ngăn cách với các phần khác của ngôi nhà bằng các tường và các sàn ngăn cháy loại 1 .

- Gian lánh nạn

- Khu vực bố trí trong tầng lánh nạn dùng để sơ tán tạm thời khi xảy ra sự cố cháy.

- Tầng lánh nạn

- Tầng dùng để sơ tán tạm thời, được bố trí trong tòa nhà có chiều cao lớn hơn $100 \mathrm{~m}$. Tầng lánh nạn có bố trí một hoặc nhiều gian lánh nạn.

- Hệ thống bảo vệ chống cháy

- Hệ thống bao gồm: Hệ thống bảo vệ chống nhiễm khỏi, hệ thống họng nước chữa cháy bên trong, hệ thống cấp nước chữa cháy ngoài nhà, các hệ thống chữa cháy tự động, hệ thống báo cháy và âm thanh công cộng, hệ thống đèn chiếu sáng sự cố và đèn chỉ dẫn thoát nạn, thang máy chữa cháy, phương tiện cứu nạn cứu hộ, giải pháp kết cấu, giải pháp thoát nạn, giải pháp ngăn khói, ngăn cháy lan.

- Tuổi thọ thiết kế

- Thời hạn sử dụng dự kiến theo thiết kế của công trình để tính toán kết cấu xây dựng (bao gồm cả phần nền móng) đảm bảo an toàn chịu lực và đảm bảo điều kiện sử dụng bình thường trong suốt thời gian khai thác và sử dụng công trình mà không phải tiến hành bất kỳ sửa chữa lớn hay gia cường kết cấu chịu lực nào.

\subsection{Tiêu chuẩn lụa chọn áp dụng}

Tiêu chuẩn kỹ thuật quốc gia hoặc tiêu chuẩn quốc tế, tiêu chuẩn khu vực, tiêu chuẩn nước ngoài được lựa chọn áp dụng cho dự án theo quy định của pháp luật hiện hành.

\section{Quan điểm về nhà ở xã hội ở một số nước trên thế giới}

Sau khi khảo sát các tài liệu (Bộ Xây dựng, 2009; Bộ Xây dựng, 2020; Bộ Xây dựng, n.d.; Dieu Hoa, 2020; Ngo, 2013; Nguyen \& Tran, 2018; Pham, 2016; Tạp chí tài chính, 2019; Tran, 2013) và các tổ chức trên thế giới nghiên cứu nhà ở cho người lao động có thu nhập thấp (Lowincome) có thể thấy rằng có nhiều trường phái về chính sách nhà cho người lao động có thu nhập thấp (Low-income) nhưng chung quy lại chỉ có 02 trường phái chính đó là

+ Chỉ dành cho những trường hợp đặc biệt như sau: 
- Không có thu nhập: Người già ở độ tuổi hưu trí đang hưởng phúc lợi xã hội

- Có thu nhập: Có công việc làm nhưng tự thân không lo nổi chổ ở cho mình nhưng phải đóng thuế thu nhập cá nhân để xét thu nhập (Income)

+ Dành cho tất cả mọi công dân có nhu cầu về nhà ở như sau:

- Không phân biệt điều kiện tài chính hoặc giới hạn về thu nhập cá nhân (Income),trường phái này chỉ thích hợp ở các quốc gia có trình độ phát triển kinh tế cao tất cả người dân có ý thức trong công việc trả góp hay trả tiền thuê nhà hàng tháng

Điều kiện thứ nhất dành cho những trường hợp đặc biệt thường sử dụng hơn điều kiện thứ hai và hầu như các nước trên thế giới sử dụng điều kiện thứ nhất này để cho thuê hoặc mua nhà trả góp như Mỹ, Canada, Pháp, Anh, Hàn Quốc, Trung Quốc...

Việc cung cấp nhà ở xã hội thể hiện ở từng quốc gia, mỗi quốc gia sẽ có điều kiện ràng buộc cho người dân nghèo của mình để đảm bảo chất lượng cuộc sống của người dân

\subsection{Tại Mỹ (USA)}

(Bộ Xây dựng, 2009; Bộ Xây dựng, 2020; Bộ Xây dựng, n.d.; Dieu Hoa, 2020; Ngo, 2013; Nguyen \& Tran, 2018; Pham, 2016; Tạp chí tài chính, 2019; Tran, 2013) theo bài viết tổng hợp và biên dịch một số tài liệu bên cạnh nguồn thông tin chính từ bài viết "Chính sách nhà ở tại Hoa $K y$ “ của Giáo sư Jonh M. Quigley, giám đốc chương trình Nhà ở và Kinh tế đô thị Khoa Chính sách công Goldman thuộc trường Đại học California, Berkeey nội dung của chương trình này như sau:

- “Affordable Housing” là một khái niệm trong chính sách nhà ở của Hoa Kỳ

- “Affordable Housing” Nhà có giá hợp lý dựa trên thu nhập (Income) của người dân

Quan điểm chung của Chính phủ Hoa kỳ là khi người dân chi trả cho nhà ở cho người có thu nhập thấp (Low - Icome) là người dân không dùng quá 30\% số thu nhập (Income) của họ cho nhà ở, gia đình nào trả hơn $30 \%$ thu nhập (Icome) cho nhà ở coi như gặp khó khăn về giá nhà và có khả năng ảnh hưởng đến các khoảng chi tiêu cho thực phẩm, quần áo,giao thông và vấn đề chăm sóc sức khỏe

Hiện nay ở Mỹ khoảng 12 triệu người, bao gồm cả người thuê và người dân sở hữu riêng hiện chi trả hơn $50 \%$ mức thu nhập (Icome) của họ cho nhà ở

Những nguyên nhân liên quan đến tầm quan trọng của chính sách nhà ở của Hoa kỳ như sau:

+ Nhà ở là tài sản riêng lẻ có giá trị nhất đối với bất kỳ gia đình hay một cá nhân nào khi gia tăng nguồn cung hoặc giảm thiểu chi phí nhà ở sẽ tác động rất lớn trong việc chi tiêu của người dân, khi giá nhà ở không biến động, lãi suất tín dụng không tăng thì giúp người dân tích lũy được vốn cũng như chi trả các chi tiêu cần thiết khác

+ Chọn lựa địa điểm cư trú của người dân có tác động qua lại cho việc phân bổ phát triển cơ sở hạ tầng đô thị.

Khi Chính phủ muốn phát triển khu dân cư nhà giá rẻ phục vụ cho người lao động có thu nhập thấp (Low-income), thì điều kiện tiên quyết đầu tiên của Chính phủ Hoa Kỳ thực hiện đó là xây dựng trường học, bệnh viện hay trung tâm thương mại sẽ trực tiếp quyết định nơi cư trú của người dân sẽ chuyển đến 
+ Chính Phủ Hoa Kỳ rất coi trọng tác động của người tiêu dùng nhà ở đến các tiêu dùng và dịch vụ khác những tác động này sẽ tác động trực tiếp đến nền kinh tế thị trường cũng như môi trường và an sinh xã hội.

Các chính sách quan trọng liên quan đến an sinh xã hội về nhà ở được ban hành bởi Chính phủ Liên bang, còn chính quyền Tiểu bang chịu trách nhiệm về chính sách nhà ở như Luật xây dựng về nhà ở, cung cấp dịch vụ. Quy mô toàn quốc chính sách liên quan nhà ở được thực hiện bởi hai cơ quan chính phủ: Tổng cục thuế (Internal Revenue Service - IRS) và Bộ Nhà ở và Phát triển đô thị (Department of Housing and Urban Development -HUD), Bộ Nhà ở và Phát triển nhà ở có nhiệm vụ mở rộng nguồn cung nhà giá rẻ cho người có thu nhập thấp (LowIncome). Các đơn vị trực thuộc như Quy hoạch và Phát triển cộng đồng, nhà ở, và nhà ở công cộng thì chủ trì nhiều chương trình với mục tiêu gia tăng nhà giá rẻ phục vụ người dân, có nhiều chính sách hổ trợ cho người dân có thu nhập thấp và người già mất sức lao động nhưng nổi bật nhất là chính sách thuế (Tax) và Chính sách trợ cấp cho người thuê nhà

Chính sách thuế: Ủu đãi thuế đối với cá nhân có khả năng về tài chánh trong việc mua nhà chính sách này được quy định tại luật Thuế thu nhập cá nhân và hàng năm tất cả người dân phải khai báo thuế thu nhập cá nhân cho Tổng cục thuế. Đối với các Chủ Đầu tư của các dự án Nhà thuê giá rẻ (Affordable Rental Housing) được quy định trong chương trình Tín dụng Thuế Nhà Ở thu nhập thấp (Low Income Housing Tax Credit - LIHTC), bên cạnh đó chính sách này còn miễn áp thuế trên thặng dư vốn đối với người trên 55 tuổi và một vài loại phí liên quan đến quyền sở hữu nhà như thuế tài sản hoặc lãi vay thế chấp có thể được giảm hoặc miễn khi tính thuế thu nhập cá nhân.

Chính sách Tín dụng thuế nhà ở thu nhập thấp (Low Income Housing Tax Credit LIHTC). Đây là chương trình hổ trợ trực tiếp của chính phủ liên bang tài trợ cho sự phát triển nhà cho thuê giá rẻ (Affordable rental housing) dành cho đối tượng người lao động có thu nhập thấp (Low Income). Năm 1986 chương trình này bắt đầu thực hiện và được mở rộng vào năm 2001 các khoản tín dụng thuế này liên bang phân bổ cho tiểu bang và sau đó Tiểu bang được phân bổ cho các doanh nghiệp đầu tư xây dựng nhà ở giá rẻ phục vụ người lao động có thu nhập thấp (Low Income)

Chính sách tín dụng thuế nhà ở thu nhập thấp (Low -Income Housing Tax Credit LIHTC) là một ví dụ điển hình trong đầu tư công - tư ( Public - Private - Partnership:PPP) dự án nhà ở thu nhập thấp khi xây dựng bắt buộc phải phù hợp với tiêu chí chung về quy hoạch, chất lượng công trình cũng như về đối tượng cư trú phải là người có thu nhập thấp khai thuế thu nhập cá nhân hàng năm và có ngưỡng thu nhập (Income) dưới mức quy định của chính phủ gọi là thu nhập thấp (Low -Income) phải phù hợp do Chính phủ Mỹ quy định. Nguyên tắc này giúp chính phủ Tiểu bang, Liên bang kiểm soát hiệu quả các cam kết của chủ đầu tư đối với chất lượng công trình và tiến độ thực hiện của dự án.

\subsection{Tại Châu Âu}

Ở nhiều nước Châu âu (Bộ Xây dựng, 2009; Bộ Xây dựng, 2020; Bộ Xây dựng, n.d.; Dieu Hoa, 2020; Ngo, 2013; Nguyen \& Tran, 2018; Pham, 2016; Tạp chí tài chính, 2019; Tran, 2013) như Pháp, Anh, Hà Lan.... Chính sách NOXH của Chính phủ rất coi trọng nơ mà Nhà nước có những can thiệp cần thiết để đạt mục đích về chính trị và an sinh xã hội. Ở thập niên 50 , 60 thế kỷ XX, NOXH là một cơ chế để giải quyết tình trạng thiếu hụt về nhà ở khi mà người nhập cư vào các đô thị tăng nhanh

Nhà ở xã hội ở Châu âu điển hình là nhà cho thuê, các hiệp hội nhà ở, công ty và hợp tác xã chi phối NOXXH và đây cũng là củ trương của Chính phủ. Do những căn hộ cho thuê đầu tư 
ban đầu không lớn hiệu quả cao phù hợp với mức thu nhập của người lao động.

Ở mỗi quốc gia tại Châu âu cơ chế cung cấp NƠXH rất khác nhau và có những hình thức trợ cấp trực tiếp tới khu vực nhà cho thuê không lợi nhuận.

\subsection{Tại Liên Hiệp Anh}

Hổ trợ trực tiếp cho xây dựng NOXXH chủ đầu tư thông qua cấp vốn và phúc lợi thuế, trợ cấp này chủ yếu cho chủ đầu tư vào dự án nhà cho thuê.

\subsection{Tại Pháp}

Nhà ở giá rẻ (HLM) cũng là loại hình của NOXH luôn luôn có sự giúp đở của Chính phủ và các đoàn thể, Chính phủ Pháp không tham gia trực tiếp vào xây dựng NƠXH mà Chính phủ tập trung vào cải thiện nhiều về chính sách tài chính về phát triển hệ thống bảo hiểm hỗ trợ cung cấp tài chính theo Luật "Liên kết đô thị " bắt buộc các địa phương phải xây dựng ít nhất là $20 \%$ NOXX nếu không thì chủ đầu tư phải nộp một khoản đóng góp cho Chính phủ vào quỹ phát triển $\mathrm{NOXH}$.

\subsection{Tại Hà Lan}

Hệ thống thẻ giảm giá khi mua nhà hay sử dụng dịch vụ và các phúc lợi xã hội khác như Y tế, Giáo dục, hình thức này khi các hộ gia đình sử dụng có nhiều lựa chọn và khi duyệt quy hoạch và xây dựng nhà ở sẽ tập trung thành từng khu, khu vực nhà thu nhập thấp riêng biệt trong cấu trúc đô thị.

\subsection{Tại Trung Quốc}

Các chính sách về nhà ở giá rẻ được các địa phương chủ động lập kế hoạch xây dựng nhà ở xã hội căn cứ vào kế hoạch đó Bộ phát triển nhà ở lập xây dựng nhà ở xã hội cho toàn quốc và thực hiện phân bổ nguồn ngân sách mà trung ương hổ trợ cho từng địa phương các doanh nghiệp tham gia xây dựng mô hình này được chính phủ miễn một số loại thuế và được chính phủ cho vay vốn. Hình thức vay vốn phục vụ cho công việc xây dựng nhà ở xã hội tại Trung Quốc có 02 loại:

+ Phương thức tạo quỹ đất xây dựng nhà ở xã hội theo đó khi xây dựng các dự án thương mại bắt buộc phải dành riêng quỹ đất 2-3\% diện tích trong dự án để xây dựng nhà ở xã hội.

+ Xây dựng nhà ở xã hội thuộc dự án riêng biệt.

Nhà ở xã hội tại Trung Quốc là dạng chung cư có 02 loại đó là Chung cư cho thuê hoặc bán theo giá chính phủ quy định, Diện tích căn hộ có 03 loại: 50-70-95m2

Đối tượng được thuê hoặc mua do chính quyền địa phương quy định việc bán cho thuê căn hộ theo hai hình thức sau đây:

+ Công ty đầu tư bất động sản bán hoặc cho thuê trực tiếp

+ Chính phủ bỏ ngân sách ra mua lại sau đó ký hợp đồng bán hoặc cho thuê giá bán, giá cho thuê bằng khoảng $50 \%$ giá thị trường.

\subsection{Tại Hàn Quốc}

Thập niên 1970 Chính phủ mạnh dạn phát triển nhà ở xã hội bằng cách đầu tư vốn vào các công ty nhà ở Hàn Quốc, đồng thời đưa ra cách tổ chức và phát triển nhà một cách hiệu quả như phát triển những căn hộ có diện tích nhỏ hướng đến phù hợp với mức thu nhập cho những đối tượng này có nhà để ở. 
Để xây dựng căn hộ này phù hợp quy hoạch và hướng đến chất lượng và tuổi thọ công trình những công ty nhà ở Hàn Quốc tìm kiếm lợi nhuận bằng cách phát triển nhà ở những đô thị lớn hướng đến những người có mức thu nhập trung bình trở lên để bù đấp khoản thâm hụt đầu tư vào căn hộ cho người có thu nhập thấp

Chính sách hổ trợ vốn của chính phủ Hàn Quốc như sau:

- Chương trình kế hoạch mua nhà lần đầu, có thể vay vốn đến $70 \%$ giá trị căn nhà với lãi suất thấp khoảng 6-6,5\%/ năm

- Chương trình "Chonsei”, cung cấp các khoản vay để mua nhà cho những người lao động làm công ăn lương có thu nhập thấp, khoản vay này có thể vay đến $70 \%$ giá trị căn hộ với lãi suất 3\%/1 năm.

- Đến năm 2000 giá đất bất động sản tại các Thành phố lớn của Hàn Quốc tăng kỷ lục, Chính phủ Hàn Quốc yêu cầu các công ty đầu tư hạn chế xây dựng chung cư cao cấp để tập trung nguồn vốn xây dựng nhà ở giá rẻ cho người có thu nhập thấp. Đồng thời chính phủ cam kết bình ổn thị trường bất động sản bằng cách tăng nguồn cung nhà siết chặt đầu cơ bất động sản, nhờ các biện pháp quyết liệt của Chính phủ Hàn Quốc hầu như người dân ai cũng có cơ hội sở hữu được căn nhà với mức giá phải chăng và phát triển nền kinh tế xã hội bền vững như hiện nay.

\section{4. Áp dụng mô hình NOXH của các nước trên thế giới có thể áp dụng vào phân khúc nhà ở chung cư cho người thu nhập thấp tại Việt Nam}

\subsection{Các chính sách về nhà ở xã hội}

Nhu cầu nhà ở xã hội ngày càng cấp bách Việt Nam (Bộ Xây dựng, 2009; Bộ Xây dựng, 2020; Bộ Xây dựng, n.d.; Dieu Hoa, 2020; Ngo, 2013; Nguyen \& Tran, 2018; Pham, 2016; Tạp chí tài chính, 2019; Tran, 2013) đang bước vào cơ số dân số vàng, với độ tuổi lao động từ 15 đến 20 tuổi chiếm khoảng $70 \%$, đặc biệt hai thành phố lớn là thành phố Hà Nội và thành phố Hồ Chí Minh người dân các tỉnh đổ về để làm việc, học tập và nhu cầu nhà ở cho các đối tượng này rất cao trong khi đó quỹ phát triển xây dựng nhà ở, giao thông và các dịch vụ công ích tiện ích đang thiếu trầm trọng và các chính sách về nhà ở xã hội được thực hiện theo Luật nhà ở 2005 (Quốc hội, 2005) với định nghĩa là NOXH "Nhà ở do Nhà nước hoặc tổ chức, cá nhân đầu tư xây dựng để cho các đối tượng quy định tại Điều 53 và Điều 54 của Luật này thuê hoạc mua”. Năm 2014 Quốc hội, Chính phủ Việt Nam đã ban hành nhiều chính sách cơ chế để phát triển NOXH để hổ trợ người lao động có thu nhập thấp gặp khó khăn về nhà ở bao gồm hai khu vực thành thị và nông thôn và trong năm này Luật nhà ở 2014 (Quốc hội, 2014a) ra đời và Nghị định 100/2015/NĐ-CPvề quy định phát triển và quản lý NOXXH (Chính Phủ, 2015b). trong Luật và Nghị định này quy định cụ thể về hổ trợ và ưu đãi để tạo điều kiện thông thoáng cho các tổ chức trong và ngoài nước tham gia đầu tư phát triển $\mathrm{NOXH}$ và ngày $25 / 1 / 2017$ Thủ tướng Chính phủ ban hành Chỉ thị số 03/CT-TTg về việc đẩy mạnh phát triển NOXH (Thủ tướng Chính phủ, 2017).

Năm 2011 Chính phủ ban hành Chiến lược phát triển nhà ở xã hội (NOXH) quốc gia (2016-2020) phải đạt ít nhất 12,5 triệu m2 sàn (NOXH), nên tháng 3 năm 2020 Chính phủ họp thường kỳ theo Nghị quyết 41/NQ-CP ngày 09 tháng 4 năm 2020 của Chính Phủ với nội dung như sau (Chính Phủ, 2020)

"Bộ Kế hoạch và Đầu tu cân đối thêm 1.000 tỷ đồng cho Ngân hàng Chính sách xã hội theo Nghị quyết số 71/2018/QH14 và bổ sung 2.000 tỷ đồng để cấp bù lãi suất cho 04 ngân hàng thuơng mại do Ngân hàng Nhà nước Việt Nam chỉ định để thực hiện hỗ trợ cho vay nhà ở xã hội.

Bộ Xây dựng nghiên cứu, đề xuất sưa đổi, bổ sung một số nội dung bất cập tại Nghị định 
số 100/2015/NĐ-CP để trình Chính phủ xem xét, ban hành trong quý IV năm 2020 theo trình tụ thủ tục rút gọn; đề xuất đổi mói phưong thức, cơ chế chính sách để giải quyết căn bản nhà ở cho các đối tương thu nhập thấp.

Bộ Xây dựng phối hợp với các địa phưong, đặc biệt là Thành phố Hà Nội và Thành phố Hồ Chi Minh tập trung chi đạo, triển khai thực hiện tốt các nhiệm vụ, giải pháp đẩy mạnh phát triển nhà ở xã hội, đáp úng nhu cầu của người thu nhập thất, nhất là công nhân".

Với chủ trương và đường lối chính sách hướng tới tầng lớp dân cư có thu nhập thấp tại các đô thị, khoảng $80 \%$ số sinh viên, học sinh của các trường Đại học, Cao đẳng, trung học dạy nghề và khoảng trên $80 \%$ công nhân lao động tại khu công nghiệp, khu chế xuất đang có nhu cầu nhà ở và Chính phủ cần hổ trợ hàng nghìn hộ dân theo tiêu chuẩn nghèo mới tại khu vực nông theo các chương trình:

- Chương trình nhà ở cho người có công cách mạng.

- Chương trình hỗ trợ hộ nghèo ở khu vực nông thôn.

- Chương trình xây dựng tuyến dân cư và nhà ở vùng ngập lũ Đồng bằng sông Cửu Long.

- Chương trình hỗ trợ hộ nghèo xây dựng nhà ở tránh bảo lụt khu vực Miền Trung.

- Chương trình phát triển nhà ở xã hội cho người có thu nhập thấp tại khu vực đô thị.

- Chương trình phát triển nhà ở cho công nhân ở khu công nghiệp, khu chế xuất.

- Chương trình phát triển nhà ở cho học sinh, sinh viên.

Nhưng ở thời điểm hiện tại gần hết năm 2020 đã đi hết chặng đường phát triển nhà ở xã hội ước đạt khoảng 35\% trên 12,5 triệu $\mathrm{m} 2$ và theo báo cáo hoạt động kinh doanh bất động sản của Sở Xây dựng thành phố Hồ Chí Minh như sau:

- Phân khúc căn hộ bình dân giá 20 triệu /m2 năm 2019: 12.366 căn đến năm 2020 giảm còn 163 căn chiếm tỷ lệ $1,2 \%$

- Năm 2020: 04 dự án hoàn thành với quy mô 4.204 căn hộ lũy kế giải đoạn 2016-2020 là 15.177 căn hộ.

Với kết quả này thì chiến lược phát triển nhà ở xã hội chưa hoàn thành nguyên nhân chính thiếu nguồn vốn, chi phí đầu vào quá cao đã khiến các doanh nghiệp phát triển nhà ở không còn mặn mà xây dựng nhà ở giá rẻ mặt khác vướng thủ tục pháp lý kéo dài làm khan hiếm nguồn cung, tạo đà làm tăng giá nhà ở các dự án mới và mới đây Bộ Xây dựng đã ban hành Thông tư 21/2019/TT-BXD (Bộ Xây dựng, 2019a). và QCVN 04:2019 (Bộ Xây dựng, 2019b), ngày 31/12/2019 về Quy chuẩn kỹ thuật quốc gia về chung cư có hiệu lực thi hành ngày 01 tháng 07 năm 2020 theo đó căn hộ chung cư có diện tích sử dụng tối thiểu không được nhỏ hơn $25 \mathrm{~m} 2$ để tháo gỡ những khó khăn vướng mắc khi xây dựng căn hộ nhà ở cho người thu nhập thấp.

\subsection{Kiến nghị các giải pháp thục hiện}

- Dự án căn hộ bình dân đáp ứng những tiêu chí nêu trên cho một hộ sử dụng

- Dự án nằm ở vùng ngoại thành.

+ Vị trí thuận tiện cơ sở hạ tầng kỹ thuật kết nối được với khu vực nội thành

+ Có nhà trẻ, trường học, Bệnh viện...

+ Giá cho căn hộ từ 500 triệu đến 1 tỷ đồng (chưa bao gồm thuế VAT) 
+ Tính pháp lý rõ ràng, minh bạch.

- Giai đoạn 2021 đến 2025 sẽ có nhiều giải pháp với từng nhóm sản phẩm đã được đề ra như:

+ Nhà ở xã hội cần đa dạng hóa phương thức đầu tư chủ yếu sử dụng vốn ngoài ngân sách, có chính sách hổ trợ vay vốn.

+ Nhà ở thương mại công bố sớm chỉ tiêu quy hoạch chi tiết 1/500.

+ Khuyến khích doanh nghiệp địa ốc phát triển nhà ở xã hội, phục vụ cho người có thu nhập thấp giải tỏa những hộ dân sống ven sông, kênh rạch.

+ Khu vực trung tâm thành phố hạn chế nhà ở cao tầng.

+ Khu vực quận vùng ven sẽ được ưu tiên phát triển các dự án xây dựng nhà ở mới, chung cư cao tầng dọc theo các trục giao thông công cộng lớn.

+ Tăng chỉ tiêu quy hoạch để sửa chữa các tòa nhà, chung cư có trước năm 1975

+ Các huyện ngoại thành phát triển khu đô thị mới, khu du lịch ở kết hợp sinh thái nghĩ dưỡng, khu vệ tinh, phát triển nhà theo các thị trấn, khu dân cư nông thôn.

+ Sử dụng các quỹ đất sạch (đất công) kêu gọi đầu tư theo hình thức PPP để phát triển mô hình nhà ở cho thuê có sự giám sát của Nhà nước.

\section{Kết luận}

Thực tế, phân khúc nhà ở xã hội đang vắng bóng dần trên thị trường nhà ở tại các đô thị lớn như thành phố Hà Nội và thành phố Hồ Chí Minh trong những năm gần đây giai đoạn 20102020. Trong khi, đối tượng thu nhập thấp không thể tiếp cận nhà ở thương mại và ngày càng khó khăn hơn để chương trình NOXH giai đoạn 2021-2026 đạt được mục tiêu đề ra trong những tháng cuối năm 2020 Chính phủ đã đưa ra gói hổ trợ tín dụng 1000 tỷ đồng cho ngân hàng chính sách xã hội và 2000 tỷ đồng để cấp bù lãi suất cho bốn ngân hàng thương mại để phát triển nhà ở xã hội cho người có thu nhập thấp, Nghị định 100/2015 NĐ-CP ngày 20 tháng 10 năm 2015 về phát triển và quản lý nhà ở xã hội sẽ sửa đổi và song song đó Bộ Xây dựng đã ban hành Thông tư 21/2019/TT-BXD ngày 31/12/2019 có hiệu lực thi hành ngày 01 tháng 07 năm 2020 nhằm tháo gỡ những vướng mắc tồn đọng về tính pháp lý khi xây dựng căn hộ chung cư cho người có thu nhập thấp để cho các doanh nghiệp kinh doanh địa ốc chuyên nghiệp và có uy tín trên thị trường bất động sản căn cứ vào những pháp lý nêu trên mạnh dạn đầu tư vào phân khúc nhà ở chung cư, nhà ở xã hội cho người thu nhập thấp,để từ đó ai cũng sở hữu được căn nhà hoặc đi thuê với giá phải chăng song song đó nhà nước phải mạnh tay với các doanh nghiệp đầu cơ bất động sản, những doanh nghiệp kinh doanh bất động sản không chân chính để bình ổn giá thị trường có như vậy mô hình này mới thành công ở Việt Nam.

\section{Tài liệu tham khảo}

Bộ Xây dựng. (2009). Kinh nghiệm giải quyết vấn đề nhà ở xã hội ở nước ngoài và ưng dụng tại Việt Nam [Experience in solving social housing problems abroad and applying in Vietnam]. Retrieved July 25, 2020, from https://moc.gov.vn/vn/tin-tuc/1145/51622/kinh-nghiem-giaiquyet-van-de-nha-o-xa-hoi-o-nuoc-ngoai-va-ung-dung-tai-viet-nam.aspx

Bộ Xây dựng. (2016). Thông tu 31/2016 BXD phân hạng chung cu [Circular 31/2016 BXD classification of apartments] Retrieved July 12, 2020, from https://thuvienphapluat.vn/van- 
ban/Bat-dong-san/Thong-tu-31-2016-TT-BXD-quy-dinh-phan-hang-cong-nhan-hang-nhachung-cu-338600.aspx

Bộ Xây dựng. (2019a). Thông tu 21/2019 BXD quy định quy chuẩn kỹ thuật quốc gia về chung cu [Circular 21/2019 BXD regulates national technical regulations on condominiums]. Retrieved July 12, 2020, from https://sxd.binhdinh.gov.vn/vi/news/quy-hoach-kientruc/qcvn-04-2019-bxd-quy-chuan-ky-thuat-quoc-gia-ve-nha-chung-cu-215.html

Bộ Xây dựng. (2019b). QCVN 04:2019 ngày 31/12/2019 quy chuẩn kỹ thuật quốc gia về chung cu [QCVN 04:2019 dated 31/12/2019 national technical regulation on condominiums]. Retrieved July 13, 2020, from https://sxd.binhdinh.gov.vn/vi/news/quy-hoach-kientruc/qcvn-04-2019-bxd-quy-chuan-ky-thuat-quoc-gia-ve-nha-chung-cu-215.html

Bộ Xây dựng. (2020). Nhà ở xã hội tại Việt Nam - Góc nhìn tù các cơ chế chính sách [Social housing in Vietnam - Perspective from policy mechanisms]. Retrieved July 17, 2020, from https://moc.gov.vn/t1/tin-tuc/63704/nha-o-xa-hoi-tai-viet-nam---goc-nhin-tu-cac-co-chechinh-sach.aspx

Bộ Xây dựng. (n.d.). Cổng thông tin tu liệu Bộ Xây dựng [Document portal of the Ministry of Construction]. Retrieved July 11, 2020, from https://moc.gov.vn/vn/Pages/Trangchu.aspx

Chính phủ. (2010). Nghị định số 71/2010/NĐ-CP quy định chi tiết thi hành luật nhà ở [Decree No. 71/2010/ND-CP detailing the implementation of the housing law]. Retrieved July 14, 2020, from https://thuvienphapluat.vn/van-ban/Bat-dong-san/Nghi-dinh-71-2010-ND-CP-huongdan-Luat-nha-o-107828.aspx

Chính phủ. (2013). Nghị định 188/2013/NĐ-CP về phát triển và quản lý nhà ở xã họi [Decree 188/2013/ND-CP on development and management of social housing] Retrieved July 15, 2020, from https://thuvienphapluat.vn/van-ban/Bat-dong-san/Nghi-dinh-188-2013-ND-CPphat-trien-quan-ly-nha-o-xa-hoi-213910.aspx

Chính phủ. (2014). Nghị định 79/2014/NĐ-CP quy định về PCCC [Decree 79/2014/ND-CP regulations on FPF]. Retrieved July 16, 2020, from https://thuvienphapluat.vn/van-ban/Tainguyen-Moi-truong/Nghi-dinh-79-2014-ND-CP-huong-dan-Luat-Phong-chua-chay-va-LuatPhong-hua-chay-sua-doi-241914.aspx

Chính phủ. (2015a). Nghị định 46/2015/NĐ-CP quy định chất lương -bảo trì công trình xây dụng [Decree 46/2015/ND-CP regulating the quality-maintenance of construction works]. Retrieved July 17, 2020, from https://thuvienphapluat.vn/van-ban/Bat-dong-san/Nghi-dinh100-2015-ND-CP-phat-trien-quan-ly-nha-o-xa-hoi-295027.aspx

Chính phủ. (2015b). Nghị dịnh 100/2015/NĐ-CP quy dịnh phát triển và quản lý nhà ở xã họi [Decree 100/2015/ND-CP on development and management of social housing] Retrieved July 14, 2020, from

Chính phủ. (2016). Nghị định số 32/2016/NĐ-CP quy định về quản lý độ cao chuớng ngại vật hàng không và các trận địa quản lý bảo vệ vùng trời tại Việt Nam [Decree No. 32/2016 / $\mathrm{ND}-\mathrm{CP}$ on the management of aviation obstacle elevation and airspace management battlefields in Vietnam] Retrieved July 13, 2020, from https://thuvienphapluat.vn/vanban/Bo-may-hanh-chinh/Nghi-dinh-32-2016-ND-CP-quan-ly-do-cao-chuong-ngai-vat-hangkhong-bao-ve-vung-troi-tai-Viet-Nam-311024.aspx

Chính phủ. (2017). Chỉ thị số 03/CT-TTg về tăng cuờng kiểm soát ô nhiễm môi truờng không khí [Directive No. 03/CT-TTg on strengthening control of air pollution]. Retrieved July 17, 2020, from https://thuvienphapluat.vn/van-ban/Tai-nguyen-Moi-truong/Chi-thi-03-CT-TTg2021-tang-cuong-kiem-soat-o-nhiem-moi-truong-khong-khi-462839.aspx

Chính phủ. (2019). Nghị định 40/2019/NĐ-CP quy định về bảo vệ môi trương [Decree 40/2019/ND-CP on environmental protection]. Retrieved July 11, 2020, from 
https://thuvienphapluat.vn/van-ban/Tai-nguyen-Moi-truong/Nghi-dinh-40-2019-ND-CPhuong-dan-thi-hanh-Luat-bao-ve-moi-truong-413905.aspx

Chính phủ. (2020). Nghị quyết số 41/NQ-CP ngày 09/4/2020 của Chính phủ về phiên họp Chính phủ thuờng kỳ tháng 3 năm 2020 [Resolution No. 41 / NQ-CP dated April 9, 2020 of the Government on the Government's regular meeting in March 2020]. Retrieved July 12, 2020, from https://thuvienphapluat.vn/van-ban/Bo-may-hanh-chinh/Nghi-quyet-41-NQ-CP-2020phien-hop-Chinh-phu-thuong-ky-thang-3-439408.aspx?tab=7

Dieu Hoa (2020). Bài học tù̀ Hàn Quốc về phát triển nhà xã họi [Lessons from Korea about social housing development]. Retrieved July 21, 2020, from https://reatimes.vn/bai-hoc-tu-hanquoc-ve-phat-trien-nha-o-xa-hoi-1604817001877.html

Ngo, M. L. (2013). Nhà ở xã hội - Tù kinh nghiệm thực tế tại Thượng Hải gợi ý cho nhà ở xã hội tại Việt Nam [Social housing - From practical experience in Shanghai suggesting social housing in Vietnam]. Retrieved July 22, 2020, from https://www.tapchikientruc.com.vn/chuyen-muc/kientruc-xahoi/nha-o-xa-hoi-tu-kinhnghiem-thuc-te-tai-thuong-hai-goi-y-cho-nha-o-xa-hoi-tai-viet-nam.html

Nguyen, A. T. Q., \& Tran, C, N. (2018). Kinh nghiệm phát triển nhà ở xã hôi của một số nuớc và thưc tiến tại Việt Nam [Experience in developing social housing of some countries and practice in Vietnam]. Retrieved July 15, 2020, from https://tapchitaichinh.vn/thi-truong-taichinh/kinh-nghiem-phat-trien-nha-o-xa-hoi-cua-mot-so-nuoc-va-thuc-tien-viet-nam143075.html

Pham, H. T. T. (2016). Kinh nghiệm quốc tế về phát triển nhà ở xã hội và bài học kinh nghiệm tại Việt Nam [International experiences in social housing development and lessons learned in Vietnam]. Tạp chí Khoa học Công nghệ Xây dựng, 10(3).

Quốc hội. (2005). Luật nhà ỏ [Housing law]. Retrieved July 21, 2020, from https://thuvienphapluat.vn/van-ban/Bat-dong-san/Luat-nha-o-2005-56-2005-QH116918.aspx

Quốc hội. (2014a). Luật nhà ở [Housing law]. Retrieved July 23, 2020, from https://thuvienphapluat.vn/van-ban/Bat-dong-san/Luat-Nha-o-2014-259721.aspx

Quốc hội. (2014b). Luật xây dụng [Construction law]. Retrieved July 29, 2020, from https://thuvienphapluat.vn/van-ban/Xay-dung-Do-thi/Luat-Xay-dung-2014-238644.aspx

Quốc hội. (2014c). Luật bảo vệ môi truờng [Environmental Protection law]. Retrieved July 18, 2020, from https://thuvienphapluat.vn/van-ban/Tai-nguyen-Moi-truong/Luat-bao-ve-moitruong-2014-238636.aspx

Quốc hội. (2020). Luật bảo vệ môi trường [Environmental protection law]. Retrieved July 16, 2020, from https://thuvienphapluat.vn/van-ban/Tai-nguyen-Moi-truong/Luat-so-72-2020QH14-Bao-ve-moi-truong-2020-431147.aspx

Quốc hội. (2020). Luật xây dựng [Construction law]. Retrieved July 11, 2020, from https://thuvienphapluat.vn/van-ban/Xay-dung-Do-thi/Luat-Xay-dung-sua-doi-2020-so-622020-QH14-418229.aspx

Tạp chí tài chính. (2019). Nhà ở xã hội và bài học tù Mỹ [Social housing and lessons from America]. Retrieved July 18, 2020, from https://tapchitaichinh.vn/thi-truong-tai-chinh/nha-oxa-hoi-va-bai-hoc-tu-nuoc-my-303573.html

Tran, T. N. D. (2013). Chính sách nhà ở cho nguời thu nhập thấp tại Mỹ [Housing policy for lowincome people in the US] Retrieved July 20, 2020, from http://bmktcn.com/index.php?option=com_content\&task=view\&id=6257\&Itemid=226 